\title{
Sistem Informasi Manajemen Pembelian dan Penjualan Pada Apotek Berkah
}

\author{
Sandy Akbar Siregar \\ Prodi Sistem Informasi, Fakultas Sains Dan Teknologi,UINSU \\ sandyakbar58@gmail.com
}

\begin{abstract}
ABSTRAK
Apotek Berkah adalah toko obat yang dipenuhi dengan penawaran obat-obatan. Apotek Berkah saat ini bekerja dalam kerangka yang sebenarnya menggunakan kerangka manual, khususnya ukuran penanganan informasi yang masih dalam bidang akuntansi sehingga secara berkala mengalami permasalahan seperti estimasi, persediaan obat, transaksi dan nomor bisnis.
\end{abstract}

Setelah mendominasi kasus-kasus saat ini, kerangka informasi transaksi dan pembelian papan direncanakan menggunakan metode perbaikan perancangan Situs, setelah itu dieksekusi dengan bahasa pemrograman sebagai kumpulan datanya.

Motivasi di balik pemeriksaan ini adalah dengan tujuan agar perwakilan dapat dengan mudah dan cepat membuat persediaan obat, data tentang pembelian obat, transaksi mekanis, secara efektif membuat laporan pembelian dan nomor bisnis, dan membuat grafik transaksi di Apotek Berkah. Hasil akhir dari pengujian ini adalah sebagai kerangka kerja data beli dan transaksi untuk menangani informasi setelah ditangani untuk menghasilkan imbal hasil sebagai nomor pemasaran dan laporan pembelian.

Kata kunci:Sistem informasi manajemen,pembelian,penjualan, 


\section{PENDAHULUAN}

Inovasi PC dan web saat ini tidak, pada saat ini mahal dan merepotkan, namun telah menjadi prasyarat mendasar untuk menyiapkan dan memperdagangkan data dalam skala terdekat dan dunia. Pemanfaatannya tidak terbatas pada satu alasan, namun berbeda tujuan dan kegunaannya untuk bisnis dan tujuan yang berbeda. Apotek Berkah merupakan organisasi yang bergerak dalam bidang penjualan obat-obatan. Saat ini, Apotek Berkah memiliki banyak persediaan klinis, beberapa di antaranya menggunakan Microsoft Dominate untuk persiapan informasi, misalnya, menangani informasi pembelian dan laporan pembelian.

Untuk sementara, beberapa penanganan informasi masih bersifat manual, dimana pembukuan sudah selesai termasuk persediaan obat, informasi provider, deal, obat obatan dan nomor bisnis. Penyiapan informasi manual sering menimbulkan masalah, termasuk akuntansi dan pengendalian persediaan dan pengembalian atau pengembalian obat. Ini akan menghambat pembuatan laporan kesepakatan pengobatan, dan akan membutuhkan waktu lama untuk memeriksa persediaan obat yang dapat diakses. Secara bersamaan, ketika klien / pasien bersiap untuk minum atau mengembalikan obat, perwakilan mengalami masalah dalam menemukan informasi bisnis untuk obat tersebut, mencari salah satu dari dua catatan transaksi.

Untuk mengurangi kesalahan dan meningkatkan sifat toko obat ini (misalnya, untuk memperluas pelaksanaan dan mempermudah perwakilan untuk menangani informasi), kerangka kerja penggambaran diharapkan membantu menyiapkan informasi penawaran, persediaan obat, informasi penyedia, membeli informasi, membeli laporan dan nomor pemasaran. Mengingat fondasi di atas, penulis esai akan menggunakan bahasa pemrograman

Dalam pengaturan ini pertanyaan mungkin muncul, khususnya bagaimana menggunakan dialek pemrograman PHP dan MySQL sebagai kumpulan data untuk merencanakan dan membuat pertukaran kerangka data eksekutif di Apotek Berkah. Untuk membidik pembicaraan 
tentang tujuan yang ideal, sejauh mana penyelidikan diklarifikasi.Masalah - masalahyang akan dibahas hanya dibatasi pada masalah-masalah sebagai berikut :

Sistem informasi ini dirancang untuk mendukung pengolaan data di Apotek Berkah.

$>$ Sistem informasi ini meliputi pengolahan data sebagai berikut :

- Data Obat

- Penjualan

- Data Supplier

- Data Karyawan

- Data Pembelian

- Resep Obat

- Laporan Penjualan

- Laporan Pembelian

- Grafik Penjualan

- Retur Penjualan

\section{STUDI LITERATUR}

Bagian ini berisi strategi untuk kemajuan kerangka kerja, penelitian masa lalu dan pembentukan hipotetis yang menggabungkan pemahaman kerangka kerja, informasi, papan, kerangka informasi, kerangka informasi eksekutif, pembelian, penawaran, toko obat, MySQL, UML, grafik use case, grafik pergerakan, dan kelas. grafik.

\subsection{Kerangka kerja}

Kerangka kerja adalah suatu organisasi metodologi yang saling berhubungan, berkumpul untuk melakukan suatu gerakan atau menyelesaikan suatu tujuan tertentu. Kerangka kerja adalah perkembangan dari setidaknya 2 segmen yang saling terkait dan diidentifikasi dengan tujuan pencapaian. Sebagian besar kerangka kerja terdiri dari subsistem yang lebih sederhana yang membantu kerangka kerja yang lebih besar.

\subsection{Informasi}

Informasi akan menjadi data yang telah dimasukkan ke dalam pengaturan yang memiliki arti dan berharga bagi masyarakat. informasi akan menjadi data yang ditangani menjadi struktur yang lebih bermanfaat dan lebih signifikan bagi individu yang mendapatkannya.

\subsection{Eksekutif}

Eksekutif adalah interaksi yang dilakukan untuk mengetahui tujuan hierarkis melalui serangkaian latihan melalui pengaturan, pemilahan, koordinasi, dan pengendalian individu dan aset otoritatif lainnya. Berdasarkan pemahaman di atas, dapat disimpulkan bahwa administrasi 
pada dasarnya adalah keahlian atau siklus pencapaian sesuatu yang berhubungan dengan menggunakan pencapaian tujuan.

\subsection{Data kerangka inklusi}

Data Kerangka inklusi menggabungkan berbagai segmen (manusia, PC, inovasi inklusi, dan instrumen kerja), ada sesuatu yang disiapkan (informasi sebagai inklusi), dan diharapkan dapat mencapai suatu tujuan atau sasaran yang kerangka inklusi dibuat oleh peneliti dan kepala untuk menyelesaikan tugas eksplisit tertentu yang mendasar untuk kerja asosiasi. Penugasan ini berkisar dari penanganan informasi langsung, misalnya, menyiapkan permohonan kepada klien, hingga administrator investigasi modern yang digunakan untuk menyiapkan alasan tindakan hierarkis.

\subsection{Kerangka data eksekutif}

Kerangka data eksekutif adalah kerangka data yang digunakan untuk memberikan inklusi yang digunakan untuk membantu aktivitas, pengurus, dan dinamika dalam suatu perkumpulan. Biasanya, itu membuat penyertaan ke eksekusi layar, menjaga koordinasi, dan memberikan data ke aktivitas asosiasi. Untuk sebagian besar, ia menyelami informasi dengan bertukar kerangka kerja persiapan.

\subsection{Transaksi}

Transaksi adalah upaya terkoordinasi untuk mendorong rencana utama yang ditujukan untuk memenuhi persyaratan dan keinginan pembeli, untuk mendapatkan kesepakatan yang menciptakan keuntungan. Kesepakatan adalah jiwa dari sebuah organisasi, karena kesepakatan dapat memperoleh manfaat seperti halnya dorongan untuk menarik pelanggan yang diperjuangkan. mengetahui daya tarik mereka sehingga mereka dapat menemukan konsekuensi dari barang-barang yang dikirimkan oleh toko obat

\subsection{MySQL}

MySQL adalah basis informasi dengan karakter opensource, artinya setiap orang dapat memanfaatkannya dan amp; menyebarkan kapasitas untuk digunakan tanpa dikenakan biaya dengan cara apa pun, juga dikenal sebagai gratis.

MySQL memiliki 3 sub-dialek, yaitu Bahasa Definisi Data, Bahasa Kontrol Data, Bahasa Kontrol Data. DLL berperan dalam artikel kumpulan data, misalnya membuat tabel, me-refresh tabel, dan menghapus tabel. DML membuat item tabel, misalnya melihat, menambah, menghapus dan amp; mengubah substansi tabel. Kemudian lagi, DCL adalah untuk tujuan keamanan kumpulan data, misalnya menyimpan hak akses ke kumpulan data dan amp; menghilangkan keuntungan yang bersumber dari kumpulan data. 


\subsection{UML}

UML adalah bahasa visual untuk mendemonstrasikan dan amp; korespondensi tentang kerangka kerja yang memanfaatkan memakai grafik dan amp tulisan pendukung. UML hanya mengambil bagian untuk menampilkan. Jadi pemanfaatan UML tidak terbatas pada sistem tertentu, meskipun sebagai aturan umum UML digunakan secara luas dalam teknik yang diatur objek. UML ada dengan alasan bahwa ada persyaratan untuk tampilan visual untuk menunjukkan, menggambarkan, merakit, dan amp, dokumentasi tergantung pada sorotan pemrograman.

\section{METODE PENELITIAN}

Bagian ini berisi garis besar noneksklusif yang menggabungkan gambaran umum di Apotek Berkah, konstruksi hierarki dan rangkaian tanggung jawab yang sebenarnya ada di Apotek Berkah dan tentang pemeriksaan dan rencana UML, basis informasi, rencana menu. Berikutnya adalah metodologi kerangka kerja yang sekarang berjalan di Apotek Berkah.

\section{Pembelian Obat}

- Semua stok obat yang sedikit atau kosong akan dicatat oleh pekerja dalam buku yang jelas

- Pemilik toko obat akan mengubah informasi tentang obat yang akan dibeli

- Pemilik toko obat membuat Surat Permintaan (SP)

- SP akan diberikan ke penyedia, dan obat yang diminta sebenarnya disampaikan ke toko obat

- Obat yang dibeli akan diperiksa oleh perwakilan depan, setelah itu akan segera diberikan kepada Rekan Spesialis

- Kolaborator spesialis obat akan memasukkan informasi obat ke dalam buku stok obat dengan menggunakan tanda terima

\section{Penjualan Obat (Non-Resep)}

- Pasien yang perlu membeli obat akan bertanya kepada pekerja setiap saat

- Pekerja akan mencari obat, baik obat di depan maupun di belakang

- Bagi pekerja yang benar-benar mengetahui pengobatan tidak memerlukan investasi untuk memberikan data obat kepada pasien, sedangkan untuk perwakilan yang tidak memiliki gambaran yang paling kabur tentang obat tersebut akan membutuhkan investasi.

- Kemudian pekerja akan meletakkan data nilai pengobatan pada pasien

- Pertukaran transaksi akan dicatat pada catatan bisnis dan akan dimasukkan dalam daftar penjualan 
- Register penjualan tidak dapat menawarkan tanda terima kepada pasien

- Jika pasien meminta tanda terima bisnis, perwakilan tersebut akan menyusun informasi penawaran obat di atas kertas transparan

3.Penjualan Obat(Resep)

- Pasien akan memeriksa biaya pengobatan dan meletakkannya di perwakilan depan

- Pekerja depan akan memberikan solusi pada asisten spesialis obat

- Kolega spesialis obat akan mencari obat sesuai indikasi pengobatannya, semakin cepat rekanan spesialis obat tersebut mengetahui informasi solusi untuk obat tersebut, semakin cepat pengecekan nilai akan selesai

- Pada saat itu solusi pengobatan akan ditawarkan kembali kepada petugas depan, perwakilan depan akan memanggil nama pasien dan memberikan data kepada pekerja tersebut.

- Setelah pasien setuju untuk memeriksa pengobatan obat, rekanan spesialis obat akan mengatur pengobatan

4.Laporan penjualan

- Setelah petugas menutup, petugas akan membuat bagan bisnis dan memeriksa kas absolut di kasir penjualan menggunakan kas lengkap yang ada di catatan bisnis

- Jika keduanya layak, panitera dapat dengan cepat membuat laporan, namun ketika ada perbedaan nilai, panitera akan mencari informasi catatan transaksi secara individual dan usia laporan akan ditunda

- Semua laporan tanda terima bisnis akan disusun oleh perwakilan di buku bagan pemasaran

Berdasarkan analisis sistem yang berjalan pada Apotek berkah ada beberapa masalah yang terjadi ,yaitu

- Sistem saat ini belum bisa mengecek obat penenang dengan cepat karena mereka masih menggunakan kerangka manual, misalnya mencari obat yang tepat terlebih dahulu, maka klien harus menahan diri untuk melihat apakah obat tersebut tersedia atau tidak.

- Kerangka kerja saat ini melakukan penanganan informasi secara fisik, misalnya transaksi dan pembelian baru saja dicatat dalam catatan, strategi ini akan memakan banyak waktu dan kemungkinan kesalahan. 
- Kerangka kerja yang berjalan tidak dapat secara konsekuen memberikan tanda terima / catatan transaksi pada klien. Jadi, ketika klien meminta catatan, pekerja akan menulis catatan di kertas bersih.

- Kerangka kerja saat ini tidak dapat membuat laporan dengan cepat dan cepat, sehingga perwakilan diperlukan untuk membuat laporan dalam waktu yang sangat lama

\subsection{Metode Pengembangan Sistem pada Sistem Informasi Manajemen Pembelian dan Penjualan pada Apotek Berkah}

Gambaran yang telah diklarifikasi tersebut dapat diartikan bahwa adalah wajar jika kemajuan sistem elektronik yang memanfaatkan strategi perbaikan desain web adalah hal yang biasa. Langkah - langkah dalam metode pengembangan sistem web yaitu:

$>$ Formulasi(formulation)

$>$ Capaian pembuatan sistem

$>$ Batasan pengembangan sistem

\section{PEMBAHASAN}

\subsection{Implementasi Sistem}

Setelah kerangka diselidiki dan direncanakan secara mendalam, tahap selanjutnya adalah eksekusi. Tahap pelaksanaan kerangka kerja adalah fase perawatan kerangka agar dipersiapkan untuk kegiatan. Eksekusi kerangka kerja juga merupakan siklus pembuatan dan pelaksanaan kerangka kerja total, baik peralatan maupun pemrograman.

\subsection{Implementasi Aplikasi dan Pengujian Sistem Informasi Manajemen Pembelian dan Penjualan pada Apotek Berkah}

Eksekusi aplikasi, khususnya hasil eksekusi menunjukkan seperti yang ditunjukkan oleh rencana yang telah dibuat. Pengujian yang digunakan adalah Discovery Trying, yaitu pengujian perilaku khusus, yang berpusat pada kebutuhan praktis produk. Artinya, strategi pengujian penemuan memungkinkan Anda membuat beberapa pengaturan prasyarat informasi yang akan benar-benar memenuhi semua kebutuhan praktis program. Berikutnya adalah eksekusi aplikasi dan pengujian Kerangka Data Papan Pembelian dan Transaksi di Apotek Berkah menggunakan strategi penemuan.

\section{Pengujian pada tampilan login}


Tampilan login tersebut digunakan untuk menuju kerangka kerja dengan memasukkan username dan frase rahasia yang digunakan oleh pemilik, organisasi, juru tulis dan rekanan ahli obat. Situasi pengujian dalam melakukan acara login ini dimulai dengan memasukkan username dan frase rahasia serta hasil pengujiannya.

Informasi penyedia di klien pemilik digunakan untuk menampilkan semua informasi penyedia dan melakukan pencarian informasi, dan mencetak informasi. Keadaan untuk pengujian informasi penyedia yang ditampilkan di pemilik selesai menggunakan kontribusi nama penyedia dan menentukan tombol pengejar sehingga dapat menampilkan informasi yang ideal dan dapat mencetak informasi penyedia dengan menentukan kapasitas cetak dan hasil pengujian.

\section{Pengujian pada tampilan data karyawan pada pemilik}

Informasi perwakilan di pemilik klien digunakan untuk menampilkan semua informasi pekerja dan melakukan tampilan informasi dari nama, dan mencetak informasi. Situasi pengujian etalase informasi perwakilan kepada pemilik diselesaikan dengan memberikan nama pekerja dan menentukan tombol pertanyaan sehingga dapat menampilkan informasi yang ideal dan dapat mencetak informasi perwakilan dengan menentukan kapasitas cetak dan hasil pengujian.

\section{Pengujian pada tampilan data pembelian}

Informasi pembelian digunakan untuk melihat semua informasi pembelian yang telah dimasukkan dalam bursa pembelian dan untuk melihat informasi dari nama penyedia dan mencetak informasi tersebut. Menu informasi beli hanya dapat diakses oleh pemilik dan klien administrator. Keadaan untuk menguji penyajian informasi pengadaan dilakukan dengan menggunakan kontribusi nama penyedia dan menentukan tombol etalase oleh karena itu, saya menunjukkan informasi yang ideal dan saya mencetak informasi pembelian dan melihat seluk-beluk pembelian menggunakan karakteristik lihat kapasitas dan tes hasil.

\section{Pengujian tampilan view data pembelian}

Tampilan pekerjaan dalam informasi pembelian digunakan untuk melihat pembelian obat dari angka pembelian. Situasi pengujian untuk pertunjukan informasi pembelian selesai dengan mengkarakterisasi kapasitas tampilan untuk melihat pembelian secara lebih rinci dan hasil pengujian.

\section{Pengujian tampilan data obat pada pemilik dan admin}

Informasi obat di pemilik dan klien administrator digunakan untuk menampilkan semua informasi obat dan melakukan pencarian informasi, dan mencetak informasi. Keadaan 
pengujian penyajian informasi obat pada pemilik dan pengelola dilakukan dengan memanfaatkan nama obat yang Anda cari dan menentukan tombol pengejar agar dapat menampilkan informasi yang ideal dan dapat mencetak informasi dengan memutuskan pekerjaan cetak, misalnya hasil tes.

\section{Pengujian tampilan grafik penjualan obat}

Grafik penawaran obat digunakan untuk mengetahui informasi obat yang paling banyak terjual. Menu bagan penawaran obat hanya dapat diakses oleh pemilik dan administrator klien. Situasi pengujian untuk penyajian diagram penawaran obat diselesaikan dengan memilih kerangka waktu garis besar yang Anda butuhkan untuk menunjukkan dan memutuskan kencangkan etalase dan dapat mencetak bagan dengan menentukan cetakan kapasitas.

\section{Pengujian pada tampilan menu laporan}

Menu laporan ini menyajikan laporan-laporan yang ada di client proprietor dan panitera, khususnya laporan transaksi obat, laporan transaksi obat per periode, laporan pembelian per periode, dan laporan transaksi obat lengkap.

\section{Pengujian tampilan laporan penjualan obat}

Laporan ini menyajikan semua informasi penawaran pengobatan berdasarkan tanggal dan proyeksi pemasaran. Situasi untuk menguji tampilan laporan penawaran obat diselesaikan dengan memilih kapasitas tampilan untuk melihat seluk-beluk kesepakatan per catatan kesepakatan.

\section{Pengujian tampilan laporan penjualan obat per periode}

Etalase laporan penawaran obat per periode menunjukkan informasi penawaran tergantung pada periode tertentu, situasi pengujian laporan tes obat per periode diselesaikan dengan menentukan periode bisnis yang akan ditampilkan dengan memilih kencangkan presentasi dan dapat mencetak laporan per catatan atau semua laporan.

\section{Pengujian tampilan laporan pembelian per periode}

Laporan pembelian lihat per periode menunjukkan informasi pembelian tergantung pada periode tertentu, situasi pengujian laporan pembelian per periode diselesaikan dengan memutuskan periode pembelian yang akan ditampilkan dengan memilih pengencang presentasi dan dapat mencetak laporan pembelian yang ditunjukkan dan dapat menunjukkan pembelian seluk-beluk tergantung pada nomor pertukaran beli dengan memilih tampilan pekerjaan.

\section{Pengujian tampilan laporan total penjualan obat}


Manajer dan pemilik klien dapat melihat laporan penawaran obat, yang menunjukkan semua informasi penawaran gratis berdasarkan kerangka waktu eksplisit, pendapatan penawaran dan keuntungan dari penawaran obat. Lengkapi pengaturan yang ditunjukkan dalam bagan pemasaran absolut dari pengobatan yang dicoba dengan menentukan waktu transaksi habis-habisan dan memilih tombol lihat.

\section{Pengujian tampilan ganti password}

Situasi pengujian untuk mengubah pertunjukan perubahan frase rahasia dicoba dengan memasukkan kata rahasia lain dan menegaskan kunci rahasia dan mengatur save catch untuk meletakkan dan menjatuhkannya untuk dijatuhkan.

\section{Pengujian tampilan data karyawan pada admin}

Situasi untuk menguji penyajian data pekerja pada administrator dicoba dengan mengatur tambah data menangkap ke data baru tambahan, memasukkan nama perwakilan untuk mencari data pekerja dengan menekan tombol pengejaran, untuk mengubah untuk mengubah data pekerja, untuk menghapus ke menghapus data, dan untuk mencetak untuk mencetak data yang memikat.

\section{Pengujian tampilan transaksi pembelian}

Keadaan pengujian penyajian penukaran beli diusahakan dengan mengisi semua data beli dan menekan tombol tambah untuk memperluas data obat yang dibeli, menghapus untuk menghapus data obat yang telah diinput dan menyimpan tangkapan penukar untuk dimasukkan. pertukaran beli..

\section{Pengujian tampilan data obat pada kasir dan apoteker}

Keadaan pengujian penyajian data obat pada petugas dan dokter spesialis obat diupayakan dengan memasukkan nama obat yang perlu dilihat dengan memencet tombol inquiry, memperluas data obat dengan memencet tombol tambah data, mengubah data obat dengan menggunakan alter, menghapus data dengan memanfaatkan erase, dan memperbanyak stok obat. yang dapat diakses dengan memanfaatkan pemanfaatan tambahan.

\section{KESIMPULAN}

Berdasarkan hasil pemeriksaan, ada beberapa tujuan yang dapat ditarik dari pembentukan Kerangka Data Eksekutif Apotek Berkah, khususnya: 
1. Kerangka data ini diperlukan untuk meningkatkan sifat toko obat, seperti meningkatkan pelaksanaan pekerja dan mempermudah perwakilan untuk menangani informasi.

2. Dengan kerangka data ini, perwakilan dapat mencari informasi obat, pekerja, penyedia, pembelian, penawaran, pengobatan obat, pasien, ruang persediaan obat, dan pengembalian penawaran sesuai dengan hak akses mereka yang terpisah.

3. Ada panduan menu untuk menemukan bisnis menghasilkan periode tertentu untuk membantu dinamika sehingga lebih mudah bagi pemilik untuk memutuskan.

\section{SARAN}

Dalam pembuatan Sistem Informasi Manajemen di Apotek Berkah ini, ada beberapa ide untuk perbaikan framework, khususnya

1. Penting untuk mengembangkan informasi tentang pencampuran obat dan stok obat secara mendalam untuk menyampaikan informasi tentang bahan pengikat dan bahan pengikat yang diperlukan.

2. Dipercaya bahwa perbaikan lebih lanjut dari kerangka data ini dapat memberikan pekerjaan menu yang lebih lengkap, dan juga dapat menampilkan informasi yang lebih eksplisit dan lebih jelas, misalnya, pengembalian pembelian, garis besar kesepakatan resep, diagram pembelian dan persamaan duplikat.

3. Pertukaran kesepakatan obat masih bergantung pada kode obat, dan dipercaya bahwa gadget yang memiliki label standar dapat digunakan untuk pergantian acara di masa mendatang.

4. Untuk tambahan turn of event, diperlukan pemeliharaan framework, termasuk dukungan peralatan dan pemeliharaan penggunaan framework informasi penyusunan, dengan tujuan agar dapat dimanfaatkan secara ideal, salah satunya adalah keamanan informasi.

5. Kerangka data ini hanya digunakan oleh satu divisi / perwakilan secara pivot, dipercaya dapat dibuat dengan sangat baik dengan mengisolasi pemanfaatan pekerja menjelang awal hari dan malam nanti.

6. Sistem informasi ini juga dapat dikembangkan di Android sehingga pasien dapat menggunakan serbaguna untuk menyelesaikan permintaan seperti memeriksa biaya obat. 


\section{DAFTAR PUSTAKA}

Adiwinoto, Bambang dan Anisah. Merencanakan dan Membuat Kerangka Informasi Beli Uang untuk Mencetak Grow PC dan amp; Studio Pangkalpinang dengan Sistem Pengaturan Artikel. Kelas Publik Inovasi Media Informasi dan Interaktif 2014 STMIK AMIKOM Yogyakarta, ISSN: 2302-3805, 2014

Agus Salim. Kerangka Informasi Transaksi Obat di Klinik U 'Budiyah Indonesia Toko obat memakai Visual Essential 6. 0. Proposisi. STMIK U 'Budiyah Indonesia Banda Aceh, 2012.

Andrian Allegra Shawabi. Penawaran dan Pengamatan Kerangka Informasi di Toko Illustrious Engine Bandung. Setiap hari Pc Logical and Informatics Version 1 Volume 1, ISSN: 2089-9033, February 2014.

Jogiyanto. Pemeriksaan dan amp; Konfigurasi Kerangka Informasi: Metodologi Terorganisir, Hipotesis dan Pemanfaatan Aplikasi Bisnis. Yogyakarta: ANDI, 2005

Kadir, Abdul. Prolog untuk Kerangka Informasi Rilis yang Ditingkatkan. Yogyakarta: ANDI, 2014. 
Laudon Kenneth C. terlebih lagi, Laudon Jane Cost. Kerangka Informasi Eksekutif: Berurusan dengan Bisnis Komputerisasi Versi kedelapan Interpretasi: Erwin Philippus. Yogyakarta: ANDI, 2005.

Nurdiansyah dan Triyono Ramadian Agus. Pembuatan Kerangka Informasi Toko Obat Berbasis Situs di Toko Obat Tulakan. IJNS Volume 2 Nomor 3 ISSN: 2302-5700, Juli 2013.

Pressman Roger S. Desain Aplikasi: Metodologi Pakar (edisi kelima). New York: McGraw Slope, 2010.

Romney Marshall B. lebih lanjut, Steinbart Paul John. Kerangka Informasi Pembukuan Tafsir: Kiki Sakinah Nur Safira dan Novita Puspitasari. Jakarta: Salemba 4, 2015

anjaya Ridwan dan Purbo Onno Widodo. Buku Brilliant Web Membuat Aplikasi WAP dengan PHP. Jakarta: PT Elex Media Komputindo, 2001.

Sari Yulida Manda dan Rusliyawati. Kerangka Informasi Pembelian dan Transaksi Narkoba di Apotek Agung Samratulangi. Setiap hari Teknokompak, Vol 10, Number. 1, 2013, 21 26, ISSN: 1412-9663, 2013.

Scott George Maywood. Standar Interpretasi Kerangka Informasi Dewan: Achmad Nashir Budiman. Jakarta: PT RajaGrafindo Persada, 2001.

Seto Soerjono dan Nita Yunita. Badan Obat (1) Pembukuan Penting untuk Toko Obat dan Industri Obat. Surabaya: Pusat Distribusi dan Percetakan Perguruan Tinggi Airlangga, 2012.

Simarmata Janner. Merancang Situs. Yogyakarta: ANDI Yogyakarta, 2010. 
Sukamto Rosa Ariani dan Shalahudin Mutia. Perancangan Sorotan Pemrograman Terorganisir dan Artikel. Bandung: Informartika Bandung, 2014. 